\title{
Mini-incubators improve the adventitious rooting performance of Corymbia and Eucalyptus microcuttings according to the environment in which they are conditioned \\ GILVANO E. BRONDANI ${ }^{1}$, LEANDRO S. DE OLIVEIRA ${ }^{2}$, ENÉAS R. KONZEN $^{1}$, ANDRÉ L.L. DA SILVA ${ }^{3}$ and JEFFERSON L. COSTA ${ }^{3}$
}

\author{
${ }^{1}$ Federal University of Lavras, Department of Forest Sciences, Campus \\ Universitário, P.O. Box 3037, 37200-000 Lavras, MG, Brazil \\ ${ }^{2}$ Federal University of Minas Gerais, Institute of Agronomic Sciences, Av. \\ Universitária, 1000, 39404-547 Montes Claros, MG, Brazil \\ ${ }^{3}$ Federal University of Paraná, Department of Bioprocess Engineering and Biotechnology, Coronel \\ Francisco H. dos Santos, 100, Jardim das Américas, 81531-990 Curitiba, PR, Brazil \\ Manuscript received on April 25, 2017; accepted for publication on June 29, 2017
}

\begin{abstract}
We addressed a major challenge in the in vitro clonal propagation of Corymbia citriodora, Eucalyptus urophylla and E. benthamii by using an ex vitro adventitious rooting strategy in a mini-incubator. Miniincubators were placed in four environments for rooting. A shade house with no fogging system and a greenhouse with no ventilation but with a fogging environment had the best performance in terms of rooting, root growth and survival of microcuttings. Daily recording of the temperature within each miniincubator in each environment allowed the verification of negative correlations between the maximum average temperature and the survival, adventitious rooting and root growth. The ideal maximum air temperature for the efficient production of clonal plants was $28.4^{\circ} \mathrm{C}\left( \pm 5.5^{\circ} \mathrm{C}\right)$, and the minimum was $20.3^{\circ} \mathrm{C}$ $\left( \pm 6.2^{\circ} \mathrm{C}\right)$. E. benthamii was more sensitive to higher temperatures than C. citriodora and E. urophylla. Nevertheless, placing mini-incubators in the shade house with no fogging system resulted in a stable and uniform performance among the three species, with $100.0 \%$ survival and $81.4 \%$ rooting. Histological sections of the adventitious roots revealed connection with the stem vascular cambium. Therefore, our experimental system demonstrated the potential of mini-incubators coupled with the proper environment to optimize the adventitious rooting performance of microcuttings.
\end{abstract}

Key words: maximum average temperature, micropropagation, rhizogenesis, shade house, greenhouse.

\section{INTRODUCTION}

Corymbia and Eucalyptus are frequently cultivated in large-scale production systems as commercial forests aimed at the production of woody biomass.

Correspondence to: Gilvano Ebling Brondani

E-mail: gebrondani@gmail.com

* Contribution to the centenary of the Brazilian Academy of Sciences.
The international market trades considerable capital with such species, which also requires the employment of several people along the production chain (Soares et al. 2010). Studies comparing forest products, such as those provided by Eucalyptus, have also shown reduced environmental impact and reduced costs of delivered biomass of their products (Daystar et al. 2014). Therefore, Corymbia 
and Eucalyptus have been among the major trees to which researchers have devoted their studies, especially considering strategies for efficiently cloning superior genotypes, individual species or hybrids (Nourissier and Monteuuis 2008, Hung and Trueman 2011, Brondani et al. 2012, Oliveira et al. 2012, Baccarin et al. 2015, Oberschelp and Gonçalves 2016).

In recent decades, increasing research has been devoted to breeding Corymbia and Eucalyptus. As a result, vegetative propagation methods have been constantly improved to maximize clonal production, especially by tissue rejuvenation (Wendling et al. 2014a, b, 2015) and an increase in adventitious rooting (Hartmann et al. 2011, Baccarin et al. 2015, Oliveira et al. 2015). Nevertheless, considerable challenges for improving adventitious rooting have been revealed by genotypes with low performance (Brondani et al. 2012) or even with no rooting ability. Propagules obtained directly from adult trees have been especially challenging because they show low degree of tissue juvenility (Wendling and Xavier 2001).

Techniques such as micropropagation (i.e., in vitro tissue cultivation in highly controlled conditions) have been optimized for eucalypts and other hybrids (Titon et al. 2003, Hung and Trueman 2011, Brondani et al. 2012, Oliveira et al. 2012, 2015, Shanthi et al. 2015), improving the rejuvenation and reinvigoration of tissues and, therefore, increasing adventitious rooting (Shanthi et al. 2015). Such achievements have been beneficial to the large-scale clonal production systems of selected genetic materials, both in quality and quantity.

Several factors influence the performance of microcuttings, especially the environmental conditions to which the propagules are exposed during the ex vitro adventitious rooting stage and acclimatization, which interfere directly with the survival of the microcuttings. The temperature of the rooting environment must be highlighted among the factors and has direct implications on physiological processes (Hartmann et al. 2011). High temperatures might lead to a water deficit, a condition that bursts numerous cellular processes that ultimately impairs the normal cell cycle and division (Costa et al. 2013). Under such conditions, reactive oxygen species are intensively produced, leading to membrane damage beyond repair by cells. As a result, at a certain stage, cells are no longer able to cope with the stress caused by the high temperature, impairing their survival (Tripathy and Oelmüller 2012, Bita and Gerats 2013).

Since Corymbia and Eucalyptus originated from Australia and small islands in the Pacific (Coppen 2002), their adaptation to temperature variation varies enormously. Therefore, each species requires a distinct temperature range under which optimal adventitious rooting can be achieved and newly healthy plants are then grown. The average, maximum and minimum temperatures of the day, in given time-intervals, are parameters that might be considered in establishing an optimal range. Brondani et al. (2014) reported that Eucalyptus benthamii minicuttings exhibited increased callus formation on their basal region with high temperatures, indicating the influence of maximum temperatures in rhizogenesis.

The effect of temperature on the ex vitro adventitious rooting of Corymbia and Eucalyptus microcuttings might be evaluated with small chambers that work as mini-incubators, as already tested by Brondani et al. (2012), Baccarin et al. (2015) and Oliveira et al. (2015). The miniincubator consists of a small structure prepared with plastic recipients for horticulture covered with plastic. This type of system can be used for experiments encompassing a reduced area for species of commercial interest, contributing to the understanding of the proper environmental conditions for the clonal propagation of desirable genotypes without the use of a greenhouse.

In our study, we systematically evaluated the effect of four distinct environments (shade house or greenhouse combined with different 
irrigation and ventilation schemes) on the survival and ex vitro adventitious rooting of Corymbia citriodora, Eucalyptus urophylla and E. benthamii microcuttings. In all environments, we used miniincubators for the ex vitro adventitious rooting while measuring the temperature variation within the chambers and determining the optimal range for each species. The key contribution of our results is a recommendation of the maximum temperature range for optimal adventitious rooting performance and therefore, the most appropriate environment in which the propagules should be placed.

\section{MATERIALS AND METHODS}

\section{ORIGIN OF THE GENETIC MATERIALS}

The explants of this study consisted of nodal segments of Corymbia citriodora Hook, Eucalyptus urophylla S. T. Black and Eucalyptus benthamii Maiden \& Cambage clones. The propagules were obtained from ministumps cultivated in pots conditioned in greenhouses covered with polypropylene and with no fogging system (Figure 1). The ministumps originated from cuttings of selected trees based on phenotypic variables (height, diameter, disease and insect resistance). The asepsis and in vitro introduction was performed according to Brondani et al. (2012). The microcuttings used for the experiments originated from microstumps cultivated in a culture medium under aseptic in vitro conditions over 12 months, with subcultivation every 28 days.

\section{In vitro CULTIVATION AND COLLECTION OF MICROCUTTINGS}

Nodal segments were cultivated in glass flasks $(6 \times 7 \mathrm{~cm})$ containing $40 \mathrm{~mL}$ of a WPM culture medium (Lloyd and McCown 1980), supplemented with $0.5 \mathrm{mg} \mathrm{L}^{-1}$ benzylaminopurine (BAP) and $0.05 \mathrm{mg} \mathrm{L}^{-1}$ naphthalene acetic acid (NAA) for bud multiplication, over 8 months (Figure 1). After this period, the microstumps (i.e., clusters containing several axillary buds) were transferred to glass flasks containing a WPM culture medium supplemented with $1 \mathrm{mg} \mathrm{L}^{-1}$ indole-3-butyric acid (IBA) and $1 \mathrm{mg} \mathrm{L}^{-1} \mathrm{NAA}$ for the induction of adventitious rooting of the microstumps (Figure 1). After two months, the microstumps that presented adventitious roots were transferred to a new WPM medium supplemented with $0.1 \mathrm{mg} \mathrm{L}^{-1}$ IBA and $0.1 \mathrm{mg} \mathrm{L}^{-1} \mathrm{NAA}$ for two more months (Figure 1). Thereafter, the microstumps started producing stem microshoot, here referred to as microcuttings, in time intervals of 14-21 days, as described by Brondani et al. (2012). The microcuttings were then collected for the experiments, as shown in Figure 1.

\section{CULTURE MEDIUM PREPARATION AND \\ INCUBATION CONDITIONS}

The culture medium was prepared with sterilized and deionized water with $7 \mathrm{~g} \mathrm{~L}^{-1}$ agar and $30 \mathrm{~g} \mathrm{~L}^{-1}$ sucrose. Before adding agar, the $\mathrm{pH}$ was adjusted to 5.8 with $0.1 \mathrm{~N} \mathrm{HCl}$ or $0.1 \mathrm{~N} \mathrm{NaOH}$. The medium was sterilized at $121^{\circ} \mathrm{C}\left(\sim 1.0 \mathrm{kgf} \mathrm{cm}^{-2}\right)$ for 20 minutes. The plant growth regulators (BAP, NAA or IBA) were added to the culture medium before sterilisation. The plant tissues were cultivated in a growth room with a controlled temperature $\left(25^{\circ} \mathrm{C} \pm\right.$ $2^{\circ} \mathrm{C}$ ) and photoperiod of 12 hours, with a luminosity of $40 \mu \mathrm{mol} \mathrm{m} \mathrm{m}^{-2}$.

\section{SHOOT COLLECTION AND MICROCUTTING STANDARDS}

The microstumps emitted microshoots after 14 and 21 days. After 28 days, the microcuttings were collected and stored in Petri dishes containing distilled and sterile water. Following propagule collection, we standardized all microcuttings with the elimination of the basal leaf (Figure 1). Overall, the average length of each microcutting was $4 \mathrm{~cm}( \pm$ $1 \mathrm{~cm})$. The microcuttings were then planted in miniincubators (Figure 1), as described by Brondani et al. (2012). The microcuttings received no treatment 
with plant growth regulators at this stage.

\section{MINI-INCUBATOR DESCRIPTION}

The mini-incubator consisted of a tray of rectangular cells (used in horticulture) with dimensions $47 \times 17 \times 3 \mathrm{~cm}$. Each cell was filled with organic compost of decomposed Pinus bark mixed with fine vermiculite. The mini-incubator was covered with a polyethylene bag and tightened at the edges to avoid variation in the relative air moisture with the other mini-incubators. The water content of each mini-incubator was controlled daily with the addition of 20-50 mL of distilled water to prevent the substrate from drying.

\section{TREATMENTS AND EXPERIMENTAL DESIGN}

The microcuttings of all species were planted in the same mini-incubator (experimental unity), for a total of four mini-incubators (Figure 1 and Figure 2). Each mini-incubator was placed in distinct environments for inducing adventitious rooting. The experiment was performed in a completely randomized design with a factorial arrangement $(3 \times 4)$. The first factor included three species ( $C$. citriodora, E. urophylla and E. benthamii). The second factor consisted of four distinct environments in which the mini-incubators were placed (Figure 1). Each microcutting was considered one replicate. The number of microcuttings varied according to the in vitro production (i.e., from 20 to 60 microshoots). The shade house was covered with $50 \%$ black mesh. The automated greenhouse was maintained at an air temperature between $25^{\circ} \mathrm{C}$ and $31^{\circ} \mathrm{C}$, and the air relative humidity was higher than $80 \%$. The ventilation system and a microsprinkler system (i.e., nebulization, applied a water system pressure of $2.0 \mathrm{kgf} \cdot \mathrm{cm}^{-2}$ ) were activated in predetermined intervals controlled by a timer.

\section{DATA COLLECTION}

We evaluated the survival of the microcuttings (SUR), the percentage of callus induction (CAL), the percentage of adventitious rooting (RO), the number of roots per plant (NR) and the total length of the root system per plant (TLRS) after 22 days. Daily recording of the air temperature (maximum - MAX, average - AVE and minimum - MIN) was performed within each mini-incubator at four different periods of the day $(09: 30 \mathrm{~h}, 12: 30 \mathrm{~h}, 15: 30$ h, and 18:30 h; Figure 2). Samples of tissues were collected from the basal region of the root induction of microcuttings for histological analyses.

\section{HISTOLOGICAL ANALYSIS}

The tissue samples were fixed in a paraformaldehyde $\left(4 \%, \mathrm{v} \mathrm{v}^{-1}\right)$ and glutaraldehyde $(1 \%$ in phosphate buffer, pH 7.0) solution (Karnovsky 1965) and subjected to a series of three vacuum infiltrations $(-620 \mathrm{mmHg})$ for 15 minutes each. Next, the samples were dehydrated using an ethyl-alcohol series in increasing concentrations $(10,20,30,40$, $50,60,70,80,90$, and $\left.100 \%, \mathrm{v} \mathrm{v}^{-1}\right)$, for 10 minutes before each was embedded in a hydroxyethyl methacrylate resin (Leica ${ }^{\circledR}$, Heidelberg, Germany). Blocks containing the samples were sectioned longitudinally or transversely to a thickness of $5 \mu \mathrm{m}$ using a manual rotary microtome coupled with a C-type razor. The sections were stained with toluidine blue $\left(0.05 \%, \mathrm{v} \mathrm{v}^{-1}\right)$ in a phosphatebuffered saline and citric acid (Sakai 1973) and mounted on slides with a synthetic resin $\left(\right.$ Entellan $\left.^{\circledR}\right)$. The histological slides were analysed and photomicrographed using a light microscope (Zeiss-Jenemed $2^{\circledR}$ ) at the micrometre scale, and the images were captured using a photographic camera (Samsung ${ }^{\circledR}$, SDC-313).

\section{STATISTICAL ANALYSIS}

The data were submitted to Shapiro-Wilk $(P<$ $0.05)$ and Hartley $(P<0.05)$ tests and, if necessary, transformed accordingly with the Box-Cox method. To analyse the effect of each environment on the species, we used analysis of variance (ANOVA, $P<0.05$ or $P<0.01)$. The means were compared with Tukey's test $(P<0.05)$. Pearson correlations 


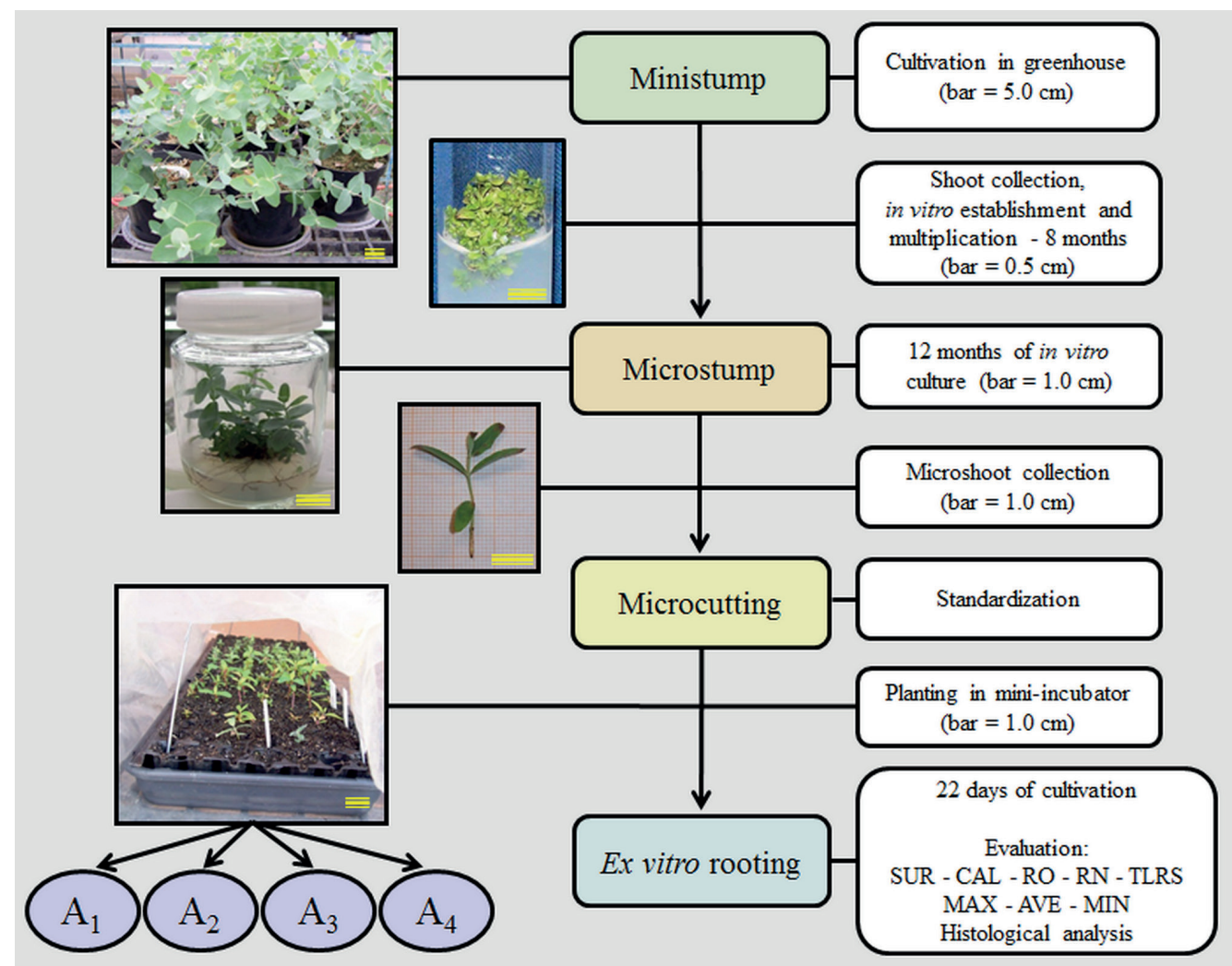

Figure 1 - Flowchart of Eucalyptus benthamii micropropagation under different environments. $\mathrm{A}_{1}-$ miniincubator placed in a shade house (50\%) with no fogging system; $\mathrm{A}_{2}-$ mini-incubator in a greenhouse with ventilation and no fogging; $A_{3}-$ mini-incubator in a greenhouse with ventilation and fogging; $A_{4}$ - mini-incubator in a greenhouse with no ventilation but with fogging. SUR - survival percentage; CAL callogenesis percentage; $\mathrm{RO}$ - adventitious rooting percentage; $\mathrm{RN}$ - number of roots; TLRS - total length of the root system; MAX - maximum air temperature; AVE - average air temperature; MIN - minimum air temperature (measured daily at 09:30 h, 12:30 h, 15:30 h, and 18:00 h). Corymbia citriodora and Eucalyptus urophylla were submitted to the same treatments.

were calculated to verify possible the correlations between the temperature and each biological variable.

\section{RESULTS}

We analysed the adventitious rooting ability of selected genotypes of C. citriodora, E. urophylla and $E$. benthamii in mini-incubator systems placed in four distinct environments (Figure 1). Our data showed that the genetic materials exhibited distinct responses in each environment. Analysis of variance (ANOVA) revealed significance interference of each environment with the adventitious rooting ( $\mathrm{RO})$, callogenesis (CAL), number of roots per plant (RN) and total length of roots per plant (TLRS). An interaction effect was detected between the environment $\left(\mathrm{A}_{1}, \mathrm{~A}_{2}, \mathrm{~A}_{3}\right.$ and $A_{4}$ ) and the species for survival (SUR) and for the total length of the roots per plant (TLRS) (Table I).

The rooting environment was crucial for the induction of rhizogenic processes in the microcuttings. Environment $\mathrm{A}_{1}(81.4 \%$ adventitious rooting) and $\mathrm{A}_{4}(73.8 \%)$ were implicated in similar levels of adventitious rooting, independent of the species. The highest average adventitious rooting rates were observed after 22 days of cultivation (Figure 3a). The environments $\mathrm{A}_{2}(43.4 \%)$ and $\mathrm{A}_{3}$ 


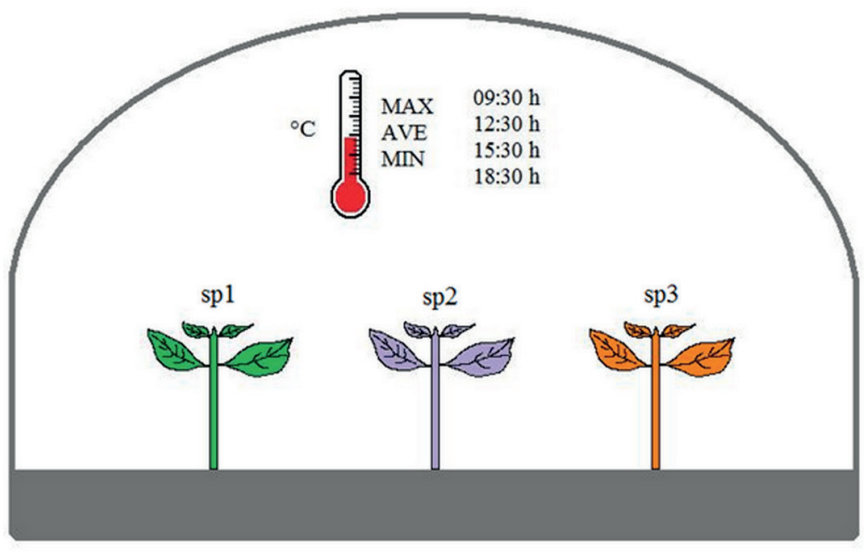

Frontal view of the mini-incubator

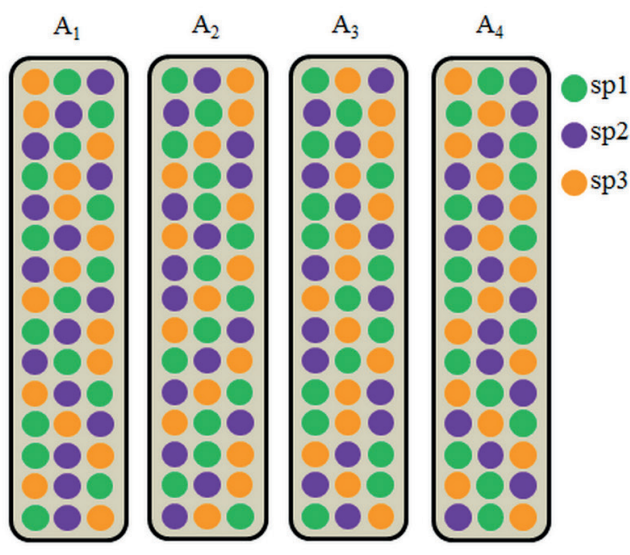

Superior view of the mini-incubator

Figure 2 - Random arrangement of microcuttings inside the mini-incubator and allocation in the rooting environment (frontal and superior view). The maximum (MAX), average (AVE) and minimum (MIN) air temperatures inside the mini-incubator were determined four times per day. $\mathrm{sp} 1=$ microcutting of Corymbia citriodora, $\mathrm{sp} 2=$ microcutting of Eucalyptus urophylla, $\mathrm{sp} 3=$ microcutting of $E$. benthamii. $\mathrm{A}_{1}$ - mini-incubator placed in shade house (50\%) with no fogging system; $\mathrm{A}_{2}-$ mini-incubator in greenhouse with ventilation and no fogging; $\mathrm{A}_{3}-$ mini-incubator in greenhouse with ventilation and fogging; $\mathrm{A}_{4}-$ mini-incubator in greenhouse with no ventilation but with fogging. $\mathrm{MAX}_{\mathrm{ikj}}=\mathrm{X}_{\mathrm{ikj}} ; \mathrm{AVE}_{\mathrm{ikj}}=\mathrm{Y}_{\mathrm{ikj}} ; \mathrm{MIN}_{\mathrm{ikj}}=\mathrm{Z}_{\mathrm{ikj}}$; where $\mathrm{MAX}=$ maximum temperature, $\mathrm{AVE}=$ average temperature, $\mathrm{MIN}=$ minimum temperature, $\mathrm{i}=$ rooting environment $\left(1=\mathrm{A}_{1}, 2=\mathrm{A}_{2}, 3=\mathrm{A}_{3}, 4=\mathrm{A}_{4}\right), \mathrm{k}=$ time of day $(1=09: 30 \mathrm{~h}, 2=12: 30 \mathrm{~h}, 3=15: 30 \mathrm{~h}, 4=18: 30 \mathrm{~h})$, and $\mathrm{j}=$ day of collection $(1, \ldots, 22) . \mathrm{MAX}_{\mathrm{i} . .}=\frac{\mathrm{r}_{\mathrm{n}}}{\mathrm{n}} \sum_{\mathrm{ikj}}^{\mathrm{n}} \mathrm{X}_{\mathrm{ikj}}=\alpha_{\mathrm{i} . . .} ; \mathrm{AVE}_{\mathrm{i} . .}=\frac{1}{\mathrm{n}} \sum_{\mathrm{ikj}}^{\mathrm{n}} \mathrm{Y}_{\mathrm{wij} \mathrm{n}}^{1} \sum_{\mathrm{ikj}}^{\mathrm{n}} \mathrm{Y}_{\mathrm{ikj}}$ $=\beta_{\mathrm{i} . .} ; \mathrm{MIN}_{\mathrm{i} . . .}=\frac{1}{\mathrm{n}} \sum_{\mathrm{ikj}}^{\mathrm{n}} \mathrm{z}_{\mathrm{ikj}}=\lambda_{\mathrm{i} . .}$; where $\alpha=$ average maximum temperature, $\beta=$ average temperature, $\lambda=$ average minimum temperature, $\mathrm{i}=$ rooting environment $\left(1=\mathrm{A}_{1}, 2=\mathrm{A}_{2}, 3=\mathrm{A}_{3}, 4=\mathrm{A}_{4}\right), \mathrm{k}=$ time of day $(1=09: 30 \mathrm{~h}, 2=12: 30 \mathrm{~h}, 3=15: 30 \mathrm{~h}, 4=18: 30 \mathrm{~h}), \mathrm{j}=$ day of collection $(1, \ldots, 22)$, and $n=$ number of observations $(n=88) . T_{i}=\frac{\alpha_{i}+\beta_{i .}+\lambda_{i .}}{n}$; where $T=$ general mean of the temperature in the mini-incubator, $\alpha$ = average maximum temperature, $\beta=$ average temperature, $\lambda=$ average minimum temperature, $i=$ rooting environment $\left(1=A_{1}, 2=A_{2}, 3=A_{3}, 4=A_{4}\right)$, and $n=$ number of observations $(n=3)$.

\section{TABLE I}

Summary of the analysis of variance (ANOVA) for the percentage of survival (SUR), percentage of adventitious rooting (RO), percentage of callogenesis (CAL), number of roots per plant (RN) and total length of the roots per plant (TLRS) of Corymbia citriodora, Eucalyptus urophylla and Eucalyptus benthamii microcuttings after 22 days in the rooting environment.

\begin{tabular}{|c|c|c|c|c|c|c|}
\hline \multirow[b]{2}{*}{ Source of variation } & \multirow[b]{2}{*}{ GL } & \multicolumn{5}{|c|}{ Mean square } \\
\hline & & $\begin{array}{c}\text { SUR }^{\mathrm{a}} \\
(\%)\end{array}$ & $\begin{array}{l}\mathrm{RO}^{\mathrm{a}} \\
(\%)\end{array}$ & $\begin{array}{c}\mathrm{CAL}^{\mathrm{a}} \\
(\%)\end{array}$ & $\begin{array}{c}\mathrm{RN}^{\mathrm{a}} \\
\left(\text { plant }^{-1}\right)\end{array}$ & $\begin{array}{c}\text { TLRS }^{\mathrm{a}} \\
\left(\mathrm{cm} \mathrm{plant}^{-1}\right)\end{array}$ \\
\hline Environment $\left(\mathrm{F}_{1}\right)$ & 3 & $0.0789^{* *}$ & $0.1707^{* *}$ & $0.0897^{* *}$ & $0.0157^{*}$ & $0.3211^{* *}$ \\
\hline Species $\left(\mathrm{F}_{2}\right)$ & 2 & $0.0068^{\text {ns }}$ & $0.0550^{\mathrm{ns}}$ & $0.0402^{*}$ & $0.0469^{* *}$ & $1.2707^{* *}$ \\
\hline $\mathrm{F}_{1} \times \mathrm{F}_{2}$ & 6 & $0.0268^{* *}$ & $0.0425^{\mathrm{ns}}$ & $0.0095^{\mathrm{ns}}$ & $0.0038^{\mathrm{ns}}$ & $0.1748^{*}$ \\
\hline Residue & 308 & 0.0079 & 0.0198 & 0.0091 & 0.0042 & 0.0628 \\
\hline Mean & - & 88.4 & 63.0 & 9.9 & 2.5 & 5.4 \\
\hline CV (\%) & - & 17.6 & 24.0 & 12.8 & 5.8 & 19.6 \\
\hline
\end{tabular}

\footnotetext{
${ }^{\text {ns }}$ non-significant, $P \geq 0,05 ;{ }^{*}$ significant at $P<0.05 ;{ }^{* *}$ significant at $P<0.01 . \mathrm{CV}=$ coefficient of variation. ${ }^{\text {a }}$ Data transformed with
} $1 / \exp (n+0.5)^{0.5}$, where $n=$ sampled data. 
(53.5\%) represented no proper conditions for the development of rhizogenic processes (Figure 3a).

An undesirable aspect under the process of adventitious rooting is the observation of callogenesis. Our data showed distinct responses of $\mathrm{CAL}$ according to the environment and the species considered. Environments $\mathrm{A}_{1}(0.0 \%)$ and $\mathrm{A}_{4}(4.2 \%)$ were implicated in the lowest average rates of callogenesis at the base of the microcuttings. Conversely, environments $\mathrm{A}_{2}(22.2 \%)$ and $\mathrm{A}_{3}$ $(13.0 \%)$ influenced the rate of callogenesis, resulting in higher values for the variable compared to the other environments (Figure 3b). Moreover, the microcuttings of $C$. citriodora $(14.6 \%)$ and $E$. urophylla (13.4\%) exhibited the highest average values of CAL, in contrast to E. benthamii (1.6\%), independent of the environment. Therefore, callogenesis was influenced by the species (Figure $3 \mathrm{c})$.

The survival of the microcuttings was one of the variables critically influenced by the species and the rooting environment, revealing distinct responses (Figure 3d). Environments $\mathrm{A}_{1}$ and $\mathrm{A}_{4}$ were the most adequate for the species evaluated, implying lower variation than the average values (from $95.1 \%$ to $100.0 \%$ survival), which were clearly influenced by higher rates of adventitious rooting.

Nevertheless, when the microcuttings were placed in environment $\mathrm{A}_{2}$, C. citriodora $(85.9 \%)$ presented the highest rate of SUR, which was significantly different from E. urophylla $(69.2 \%)$ and $E$. benthamii (56.2\%). The opposite response was observed in $\mathrm{A}_{3}$, where the microcuttings of $E$. benthamii $(100.0 \%)$ presented the highest SUR, while C. citriodora $(80.0 \%)$ and E. urophylla $(84.6 \%)$ presented similar values (Figure $3 \mathrm{~d}$ ).

Of the microcuttings that presented root induction, we evaluated the number of roots emitted (RN) and the total length of the root system (TLRS). RN was higher in $\mathrm{A}_{1}$ (2.9) and $\mathrm{A}_{4}$ (2.6) than in $A_{2}$ (2.3) and $A_{3}(2.4)$, showing that the rooting environment also influenced the growth and development of the roots after their induction (Figure 3e). The Eucalyptus species were also implicated in distinct results of the RN, since $E$. urophylla (3.2) presented the highest values in comparison to C. citriodora (2.0) and E. benthamii (2.4) (Figure 3f).

The most evident difference with regard to the root system was observed with TLRS (Figure $3 \mathrm{~g}$ ). In general, $\mathrm{A}_{1}$ showed the best conditions for root growth after induction, resulting in a range of variation of TLRS from 3.7 to $9.2 \mathrm{~cm}$. $\mathrm{A}_{2}$ showed the lowest values of TLRS (from 1.8 to 5.6). $C$. citriodora $(2.5 \mathrm{~cm})$ was the most sensitive species in $\mathrm{A}_{3}$, while higher values were measured for $E$. urophylla $(8.1 \mathrm{~cm})$ and $E$. benthamii $(6.9 \mathrm{~cm}) . \mathrm{A}_{4}$ was the only environment where no differences were detected among the species. In general, $E$. urophylla and E. benthamii showed the highest values of TLRS in all environments, while $C$. citriodora did not perform well in any of the environments. Therefore, our results suggest a strong influence of the species and genotype on TLRS (Figure 3g).

The performance of adventitious rooting verified in this study was influenced by the temperature variation within each one of the four environments $\left(A_{1}, A_{2}, A_{3}\right.$ and $\left.A_{4}\right)$. Therefore, we systematically measured the maximum (MAX), average (AVE) and minimum (MIN) temperatures inside each mini-incubator at four different periods of each day following transplantation (period of 22 days). The profile of temperature variation in each environment is shown in Figure 4. The mean air temperatures inside of the mini-incubator varied according to the environment [average ( \pm standard deviation) $]: \mathrm{A}_{1}, \mathrm{MAX}=28.4^{\circ} \mathrm{C}\left( \pm 5.5^{\circ} \mathrm{C}\right), \mathrm{AVE}=$ $24.4^{\circ} \mathrm{C}\left( \pm 5.2^{\circ} \mathrm{C}\right), \mathrm{MIN}=20.3^{\circ} \mathrm{C}\left( \pm 6.2^{\circ} \mathrm{C}\right) ; \mathrm{A}_{2}$, $\mathrm{MAX}=33.2^{\circ} \mathrm{C}\left( \pm 7.3^{\circ} \mathrm{C}\right), \mathrm{AVE}=27.8^{\circ} \mathrm{C}\left( \pm 7.0^{\circ} \mathrm{C}\right)$, $\mathrm{MIN}=22.3^{\circ} \mathrm{C}\left( \pm 8.1^{\circ} \mathrm{C}\right) ; \mathrm{A}_{3}, \mathrm{MAX}=26.3^{\circ} \mathrm{C}( \pm$ $\left.4.1^{\circ} \mathrm{C}\right), \mathrm{AVE}=22.6^{\circ} \mathrm{C}\left( \pm 4.8^{\circ} \mathrm{C}\right), \mathrm{MIN}=18.9^{\circ} \mathrm{C}$ $\left( \pm 5.9^{\circ} \mathrm{C}\right)$; and $\mathrm{A}_{4}, \mathrm{MAX}=29.0^{\circ} \mathrm{C}\left( \pm 5.2^{\circ} \mathrm{C}\right), \mathrm{AVE}$ 

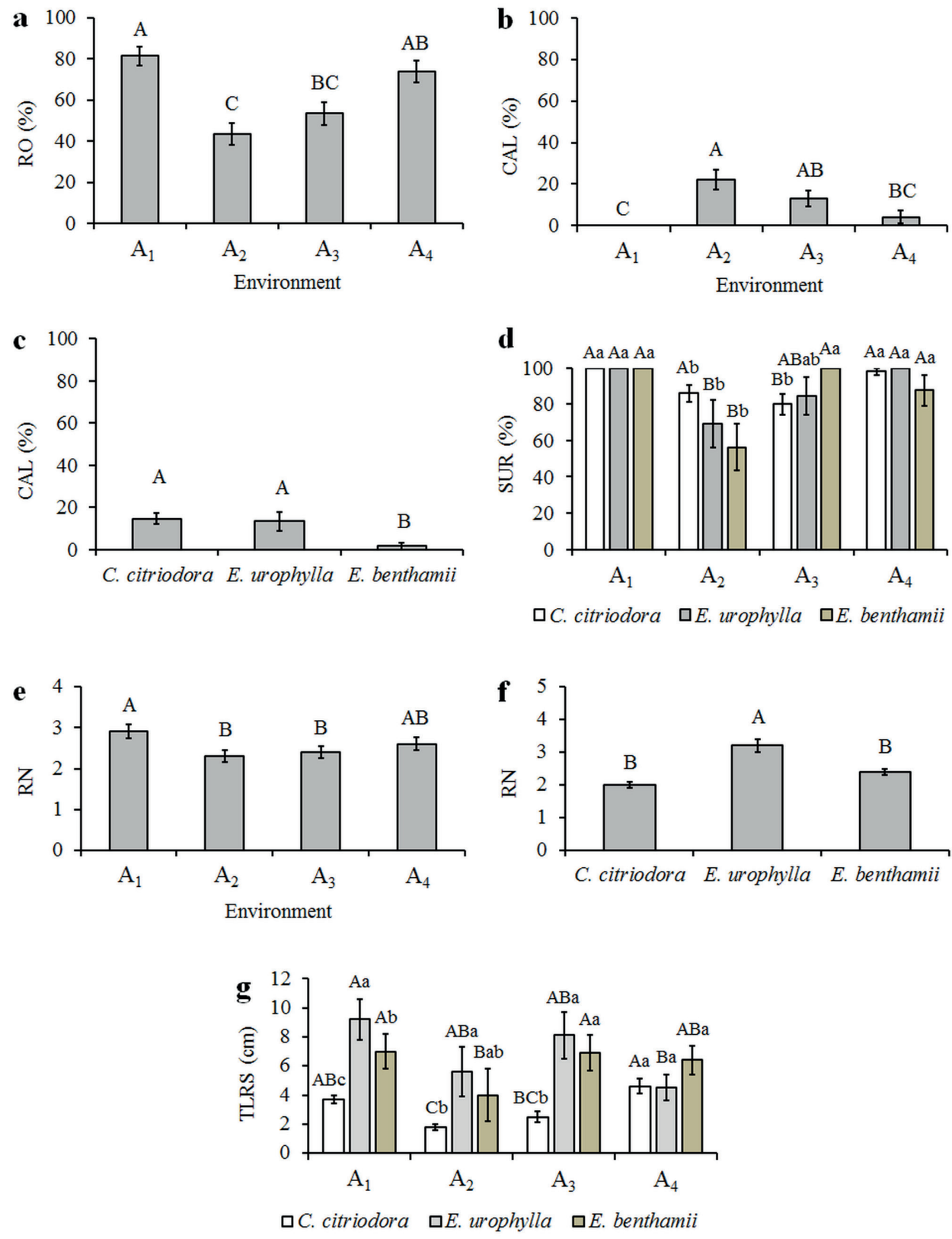

Figure 3 - Effects of distinct environments on microcuttings of Corymbia citriodora, Eucalyptus urophylla and E. benthamii after 22 days of rooting. a - Percentage of adventitious rooting (RO) in the environments. $\mathbf{b}$ - Percentage of callogenesis (CAL) in the environments. $\mathbf{c}-$ Percentage of callogenesis (CAL) for each species. $\mathbf{d}$ - Percentage of survival of the microcuttings (SUR) for each species. e - Number of adventitious roots emitted per microcutting (RN) in each environment. $\mathbf{f}-$ Number of adventitious roots (RN) per species. $\mathbf{g}$ - Total length of the roots for each microcutting (TLRS) in the environment for each species. $A_{1}$ - shade house with no fogging; $A_{2}-$ greenhouse with ventilation but no fogging; $\mathrm{A}_{3}$ - greenhouse with both ventilation and fogging; $\mathrm{A}_{4}-$ greenhouse with no ventilation but with fogging. $\mathrm{a}, \mathrm{b}, \mathrm{c}, \mathrm{e}$ and $\mathrm{f}-$ Mean values followed by the same letter represent no significant difference according to Tukey's test $(P<0.05)$. $\mathrm{d}, \mathrm{g}-$ Mean values followed by the same lowercase letter for the environment among the species, and mean values followed by the same capital letter among the environments for the same species represent no differences according to Tukey's test $(P<0.05)$. The values are presented as the mean \pm standard error. 
$=25.1^{\circ} \mathrm{C}\left( \pm 5.5^{\circ} \mathrm{C}\right), \mathrm{MIN}=21.1^{\circ} \mathrm{C}\left( \pm 6.8^{\circ} \mathrm{C}\right)$. Overall, $\mathrm{A}_{2}$ was the warmest environment, and $A_{3}$ presented the lowest temperatures. $A_{1}$ and $A_{4}$ presented intermediate temperatures (Figure 4).

The temperature data were then correlated with the biological variables measured by calculating the Pearson correlations. A graphical representation of the correlations is shown in Figure 4d-g with the maximum temperatures (MAX) only, which were significantly correlated with the variables. A negative and significant correlation $(P<0.05)$ was observed between MAX and the percentage of survival (SUR), adventitious rooting (RO) and the total length of the root system (TLRS) (Figure 4d, e and f). Conversely, a significant $(P<0.05)$ and positive correlation was detected between MAX and the percentage of callogenesis (CAL) (Figure 4g).

Our data showed that microcuttings of species that originated from subtropical or temperate climates (C. citriodora and E. benthamii) presented lower TLRS when exposed to high temperatures. For instance, the ideal maximum temperature for C. citriodora (Figure 5a-d) and E. benthamii (5i-1) was between $28.4\left( \pm 5.5^{\circ} \mathrm{C}\right)$ and $29.0^{\circ} \mathrm{C}( \pm$ $5.2^{\circ} \mathrm{C}$ ). In contrast, E. urophylla presented similar responses in environments $A_{1}, A_{2}$ and $A_{3}$ (Figure 5e-h). The root system, however, did not show a good growth performance (TLRS) in environment $\mathrm{A}_{4}$ (Figure 5h), since there was high humidity but no ventilation system. Temperatures higher than $28.4^{\circ} \mathrm{C}\left( \pm 5.5^{\circ} \mathrm{C}\right)$ were implicated in decreased root development of the species (Figure $5 \mathrm{~m}-\mathrm{o}$ ).

Histological sections of the origin of adventitious roots in the E. benthamii microcuttings revealed a direct connection with stem vascular tissue (i.e., vascular cambium). This was the region where adventitious roots emerged (Figure 5p).

\section{DISCUSSION}

The development of new techniques for the vegetative propagation and the adjustment of the diverse factors that influence plant development have been studied in an attempt to establishing efficient large-scale production systems. However, a methodology for producing clonal plants from different Corymbia and Eucalyptus mature clones is still lacking because they show particular responses to morphogenic stimuli. Micropropagation is a suitable method for cloning highly productive and genetically superior trees in large-scale production systems and in a reduced space. A major advantage of this technique is promoting the rejuvenation of plant tissues, which is achieved by adding rhizogenic competence to the propagules used for obtaining clonal plants. According to Wendling et al. (2014a,b), tissue rejuvenation in mature clones can be obtained by serial micropropagation of plants (and other techniques, e.g., pruning, serial grafting or growth plant regulator application), and complete rejuvenation is only obtained during gamete formation, sexual reproduction and embryo formation. Reinvigoration is known as false rejuvenation and refers the restoration of the vigour of the plant or other propagules by the application of cultural treatments (e.g., irrigation control, nutrient applications, pruning practices and pest control). Based on these considerations, tissue reinvigoration refers to a decrease in physiological age, whereas tissue rejuvenation refers to a decrease in ontogenetical age due to true reversion to a more juvenile phase (Wendling et al. 2014a,b), which may favour higher rooting rates of propagules.

Nevertheless, the in vitro rooting followed by acclimatization has shown limited potential, considering the low acclimatization rates due to the manipulation of roots obtained in laboratory conditions (Dutra et al. 2009, Brondani et al. 2012). Coupling the steps of rooting and acclimatization of the propagules obtained through micropropagation is then an advance in the production of clonal plants with higher quantity and quality and in less time (Dutra et al. 2009, Ruedell et al. 2013, Cordeiro et al. 2014, Oliveira et al. 2015). Our 

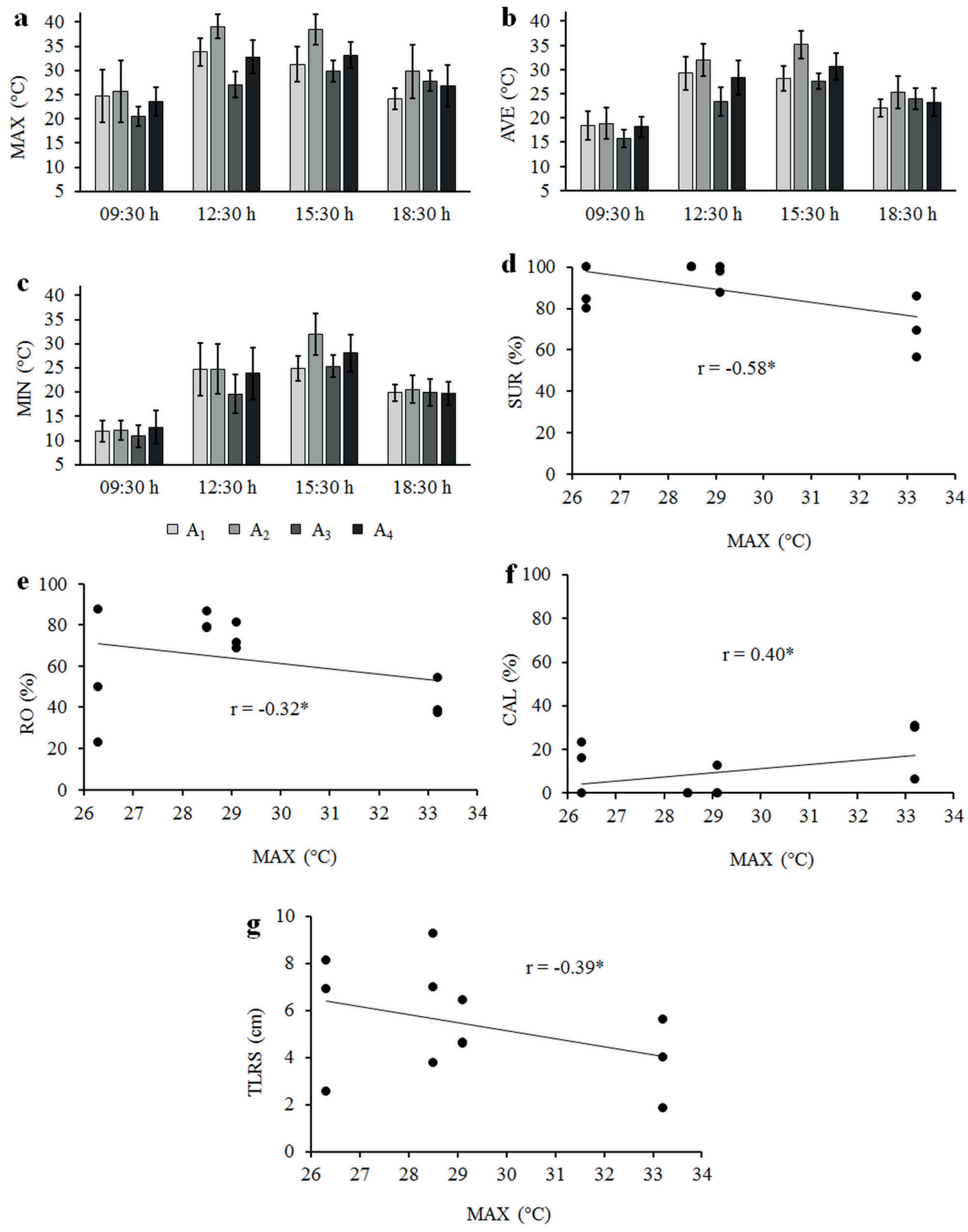

Figure 4 - Air temperatures in mini-incubators placed in four distinct environments. a - Mean values of the maximum (MAX), b - average (AVE), and $\mathbf{c}$ - minimum (MIN) temperatures. $\mathbf{d}$ - Pearson correlation between maximum air temperature (MAX) in the mini-incubators of the percentage of survival (SUR), $\mathbf{e}$ - percentage of adventitious rooting (RO), $\mathbf{f}$ - percentage of callogenesis (CAL) and $\mathbf{g}$ - the total length of the adventitious root system (TLRS) of microcuttings of Eucalyptus and Corymbia. $\mathrm{A}_{1}$ - shade house with no fogging; $\mathrm{A}_{2}$ - greenhouse with ventilation but no fogging; $A_{3}-$ greenhouse with both ventilation and fogging; $A_{4}-$ greenhouse with no ventilation but with fogging. The values are presented as the mean \pm standard error. ${ }^{*}$ Significant value $(P<0.05)$. 


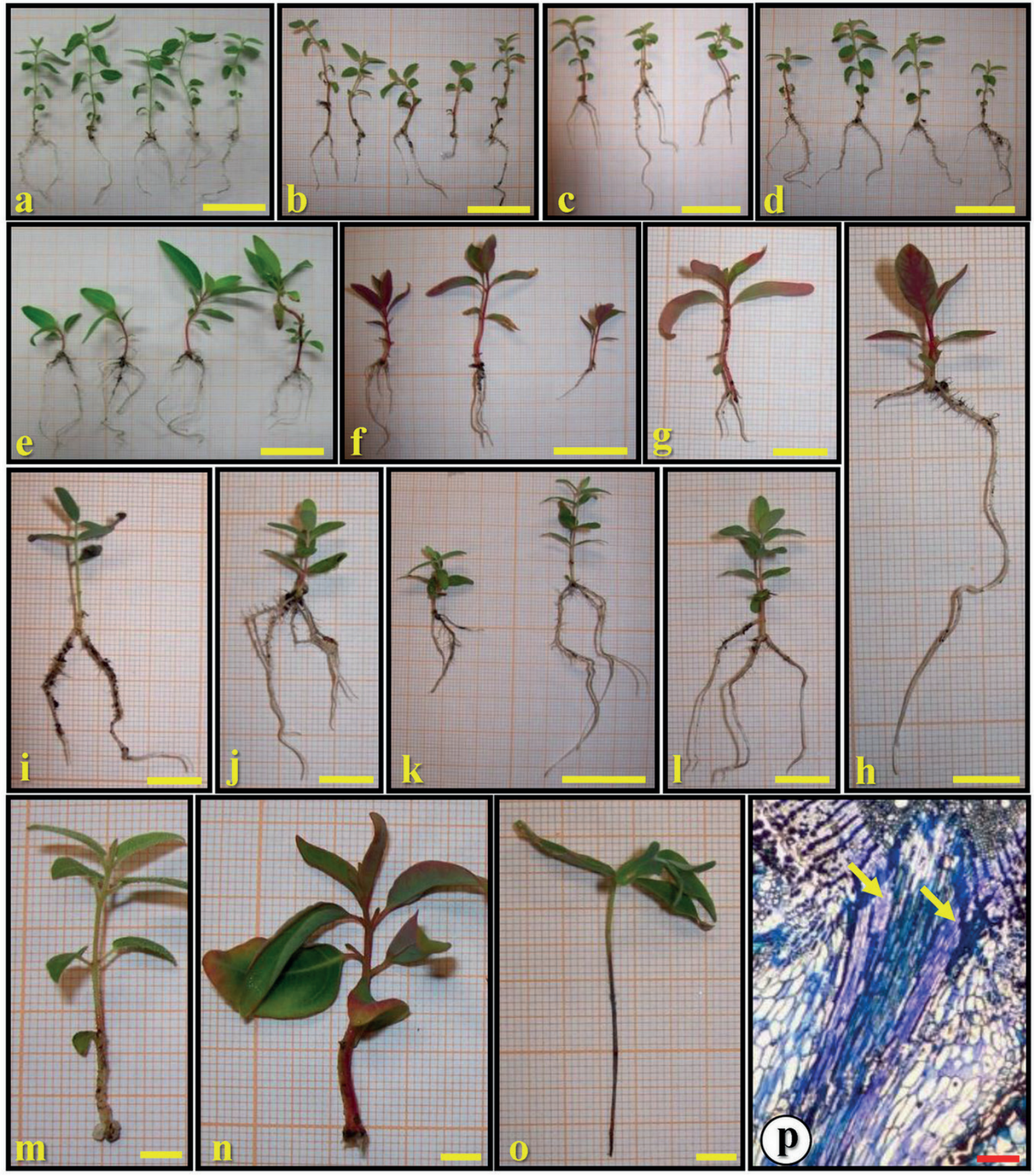

Figure 5 - Details of the adventitious rooting of Corymbia and Eucalyptus microcuttings in different environments of rooting. $\mathbf{a}-$ Corymbia citriodora in environments $\mathrm{A}_{1}, \mathrm{bar}=2.5 \mathrm{~cm} ; \mathbf{b}-\mathrm{A}_{2}, \mathrm{bar}=2.5 \mathrm{~cm} ; \mathbf{c}-\mathrm{A}_{3}, \mathrm{bar}=2.5 \mathrm{~cm} ;$ and $\mathbf{d}-\mathrm{A}_{4}$, bar $=2.5 \mathrm{~cm} . \mathbf{e}-$ Eucalyptus urophylla in environments $\mathrm{A}_{1}$, bar $=2.5 \mathrm{~cm} ; \mathbf{f}-\mathrm{A}_{2}$, bar $=2.5 \mathrm{~cm} ; \mathbf{g}-\mathrm{A}_{3}$, bar $=1.0 \mathrm{~cm} ;$ and $\mathbf{h}$ $-\mathrm{A}_{4}$, bar $=1.0 \mathrm{~cm} . \mathbf{i}-$ E. benthamii in environments $\mathrm{A}_{1}$, bar $=1.0 \mathrm{~cm} ; \mathbf{j}-\mathrm{A}_{2}$, bar $=1.0 \mathrm{~cm} ; \mathbf{k}-\mathrm{A}_{3}$, bar $=2.5 \mathrm{~cm} ;$ and $\mathbf{l}-\mathrm{A}_{4}$, bar $=1.0 \mathrm{~cm} . \mathbf{m}-$ Detail of callus induction at the base of each C. citriodora microcutting in environment $\mathrm{A}_{2}, \mathrm{bar}=0.5 \mathrm{~cm}$. $\mathbf{n}$ - Detail of callus induction at the base of $E$. urophylla microcutting in environment $\mathrm{A}_{2}$, bar $=0.5 \mathrm{~cm}$. $\mathbf{o}$ - Detail of necrosis at the base of $E$. benthamii microcutting in environment $\mathrm{A}_{2}$, bar $=0.5 \mathrm{~cm}$. $\mathbf{p}$ - Transversal section of the base of $E$. benthamii microcutting in environment $A_{1}$. The yellow arrow indicates the vascular connection between the adventitious root with the stem vascular cambium, $b a r=100 \mu \mathrm{m} . \mathrm{A}_{1}$ - shade house with no fogging; $\mathrm{A}_{2}-$ greenhouse with ventilation but no fogging; $\mathrm{A}_{3}$ - greenhouse with both ventilation and fogging; $\mathrm{A}_{4}$ - greenhouse with no ventilation but with fogging. 
study was based on an ex vitro approach for the acclimatization of clones of distinct Corymbia and Eucalyptus, revealing the potential for obtaining high adventitious rooting rates. With the method employed, we were able to reduce the number of steps between in vitro multiplication and elongation and acclimatization, thereby optimizing the micropropagation technique. An inherent advantage of the experimental system adopted in our study is the reduction of the stress to which the propagules were submitted, since only one transplantation was required (Brondani et al. 2012). The use of mini-incubators increased the protection against environmental stresses, as both temperature and air moisture were better controlled.

The internal temperature of the mini-incubator was revealed to be a key factor in the survival and adventitious rooting of the clones used in our study. The temperature range to which cuttings of woody species are usually submitted is between 15 and $35^{\circ} \mathrm{C}$ (Xavier et al. 2013). However, temperatures between 20 and $30^{\circ} \mathrm{C}$ are desirable to avoid excessive transpiration and water loss and, therefore, necrosis of the tissues (Alfenas et al. 2004). The best performances for survival and rooting of the propagules of $C$. citriodora, $E$. urophylla and $E$. benthamii were achieved with an average maximum temperature (MAX) of $28.4^{\circ} \mathrm{C}$ $\left( \pm 5.5^{\circ} \mathrm{C}\right)$ and an average minimum temperature (MIN) of $20.3^{\circ} \mathrm{C}\left( \pm 6.2^{\circ} \mathrm{C}\right)$ in environment $\mathrm{A}_{1}$ (100.0\% survival and $81.4 \%$ rooting, shade house with no fogging) and $\mathrm{MAX}$ of $29.0^{\circ} \mathrm{C}\left( \pm 5.2^{\circ} \mathrm{C}\right)$ and $\mathrm{MIN}$ of $21.1^{\circ} \mathrm{C}\left( \pm 6.8^{\circ} \mathrm{C}\right)$ in $\mathrm{A}_{4}(95.1 \%$ survival and $73.8 \%$ rooting, greenhouse with no ventilation but with fogging). Conversely, the environments $\mathrm{A}_{2}$ (greenhouse with ventilation but no fogging) and $\mathrm{A}_{3}$ (greenhouse with both ventilation and fogging) were not adequate for the establishment of the species. This result might be explained by the negative correlation between the MAX temperature and survival, adventitious rooting and total length of roots (Figure 4d-g). The average MAX temperatures of $\mathrm{A}_{2}$ and $\mathrm{A}_{3}$ were above and below, respectively, the optimal performance observed for the three species.

The high survival and rooting of microcuttings in environments $A_{1}$ and $A_{4}$ demonstrated the potential of mini-incubators combined with the greenhouse or shade house environments in producing clonal plants in a reduced space and time. In comparison with other studies developed for Eucalyptus in greenhouse conditions with mini-cuttings, our results revealed even higher survival and rooting rates. In general, mini-cuttings of eucalypts species have presented survival and rooting rates as high as $85 \%$ or more (Titon et al. 2003, Oliveira et al. 2006, Almeida et al. 2007, Borges et al. 2011, Brondani et al. 2010a, b, 2014).

The highly controlled environments used in this study provided high rates of adventitious rooting in environments $A_{1}$ (shade house with no fogging) and $\mathrm{A}_{4}$ (greenhouse with no ventilation but with fogging). In contrast, the performances of adventitious rooting and survival in environments $A_{2}$ (greenhouse with ventilation but no fogging) and $\mathrm{A}_{3}$ (greenhouse with both ventilation and fogging) were lower. An interesting result in environments $A_{2}$ and $A_{3}$ was the survival of $E$. benthamii microcuttings. The conditions of $\mathrm{A}_{2}$ (greenhouse with ventilation but no fogging) created an environment with higher temperatures (MAX, AVE, and MIN) than $\mathrm{A}_{1}, \mathrm{~A}_{3}$ and $\mathrm{A}_{4}$ (Figure $4 a-c)$. Since $E$. benthamii is from subtropical areas of southeastern Australia, the species is adapted to lower temperatures (Jovanovic and Booth 2002), but probably not the opposite. Therefore, the survival of $E$. benthamii microcuttings was lower than C. citriodora and E. urophylla. In contrast, $\mathrm{A}_{3}$ provided the lowest temperatures (MAX, AVE, and MIN), which resulted in $100.0 \%$ survival of $E$. benthamii microcuttings.

Considering the warmer environment $\left(\mathrm{A}_{2}\right), C$. citriodora had the best performance for rooting, although it was reduced $(54.3 \%)$, while in the 
colder environment $\left(\mathrm{A}_{3}\right)$, E. benthamii presented the highest rooting percentage $(87.5 \%)$. E. urophylla showed low rooting in $\mathrm{A}_{2}(38.4 \%)$ and $\mathrm{A}_{3}$ (23.0\%). This result indicates that the microcuttings of the different species require different thermal conditions for rooting to occur effectively, avoiding temperatures higher than $33^{\circ} \mathrm{C}$ and/or lower than $18^{\circ} \mathrm{C}$. Nevertheless, the rooting percentage was higher when the microcuttings were conditioned in the $\mathrm{A}_{1}$ environment, resulting in $79.1 \%$ rooting for C. citriodora, $78.5 \%$ for E. urophylla and $86.6 \%$ for E. benthamii. Despite the differences in the rooting rates, microcuttings of species can be cultivated simultaneously in the same rooting environment, since the variations of the air temperature are similar to the $\mathrm{A}_{1}$ environment.

The $A_{1}$ environment (shade house with no fogging) had the best results for survival and adventitious rooting. Moreover, we observed no callogenesis in this environment, contrary to what was observed in the others. Another highlight of this environment is the uniform survival among the species, as $100.0 \%$ of the propagules survived. Therefore, the combination between shade and mini-incubators is an efficient system for optimizing the production of clonal plants from distinct Corymbia and Eucalyptus. In contrast, environment $\mathrm{A}_{2}$ (greenhouse with ventilation but no fogging) presented high temperatures and had low performances for the variables evaluated. Moreover, in $\mathrm{A}_{2}$ we observed the highest percentage of callus induction, which negatively influences adventitious rooting and is associated with temperature stress. High temperatures alter the metabolism of the propagules and might lead to denaturation of key enzymes and the reduction in nutrient absorption, which ultimately reduces the rhizogenic capacity of tissues and promotes callus induction at the bottom of the propagules (Beeckman 2010, Hartmann et al. 2011, Trueman et al. 2013).

Another important implication of the experimental system used in this work is that the microcuttings presented high adventitious rooting ex vitro, regardless of the use of plant growth regulators, such as indole-3-butyric acid (IBA), commonly used in such experiments. Conversely, the use of IBA could possibly result in $100.0 \%$ adventitious rooting, resulting in even better performances.

Considering the development of adventitious roots, it is necessary to highlight the origin of the vascular connection with the stem tissues of the microcuttings, which can influence the survival rates of the plants during acclimatization and field planting. Our results showed the development of adventitious roots in direct connection with the stem vascular cambium without the occurrence of external callus (i.e., no indirect organogenesis, Figure 5p) in E. benthamii microcuttings in the $A_{1}$ environment. This result corroborates the observations of Brondani et al. (2012) in a study related to the adventitious rooting in microcuttings of the same species and is probably associated with the air temperature variation inside of the mini-incubator (MAX, AVE, MIN, Figure 4) in $A_{1}$, which may have favoured rhizogenesis (Beeckman 2010, Hartmann et al. 2011). According to Li et al. (2009) the presence of callus in the external tissues of propagules harms the root functionality and compromises the plant quality, characterizing an undesirable effect on the cloning system, and in the $\mathrm{A}_{1}$ environment, the microcuttings no presented callus (Figure 3).

Our results have important implications for the optimization of production systems of Corymbia and Eucalyptus using the micropropagation technique. The use of mini-incubators is a viable and important step in the acclimatization of microcuttings, combined with an appropriate environment in which they are placed. The combination of mini-incubators and a shade house were shown to be the most adequate for obtaining high performances of established plants of the three species. The critical factor, though, 
was the temperature to which the propagules were submitted, showing that controlling the maximum temperature is important for the development of the propagules. We believe that similar results might be achieved for other genetic materials and species of Corymbia citriodora, Eucalyptus urophylla and $E$. benthamii as well; however, complementary studies to test the effect of the conditions and their optimization are advised.

\section{CONCLUSIONS}

Our work provided evidence that mini-incubators placed in distinct environments influence the survival; adventitious rooting, as well as other root variables; and callogenesis of Corymbia and Eucalyptus microcuttings. A critical factor correlated with the production of clonal plants was the maximum temperature to which Corymbia citriodora, Eucalyptus urophylla and E. benthamii were conditioned during the experimental period. We verified that the ideal maximum air temperature for producing clonal plants from microcuttings of the three species was $28.4^{\circ} \mathrm{C}\left( \pm 5.5^{\circ} \mathrm{C}\right)$, and the minimum temperature was $20.3^{\circ} \mathrm{C}\left( \pm 6.2^{\circ} \mathrm{C}\right)$ over the 22 days. The most adequate environment for the ex vitro incubation of microcuttings of the three species was $A_{1}$, within the shade house (50\% shade). Histological sections of the adventitious roots that originated in E. benthamii microcuttings revealed a direct connection with the stem vascular cambium. This method represents an economically viable option because low costs are involved in constructing both shade houses and miniincubators.

\section{ACKNOWLEDGMENTS}

We thank the Coordenação de Aperfeiçoamento de Pessoal de Nível Superior (CAPES) and Conselho Nacional de Desenvolvimento Científico e Tecnológico (CNPq) for the financial support of this work. We also thank Prof. Antônio Natal
Gonçalves (ESALQ/USP) for providing the space for the conduction of the experiments and Prof. Marcílio de Almeida (ESALQ/USP) for the anatomical analysis.

\section{REFERENCES}

ALFENAS AC, ZAUZA EAV, MAFIA RG AND ASSIS TF. 2004. Clonagem e doenças do eucalipto. Viçosa, MG, Brasil: Editora UFV, 442 p

ALMEIDA FD, XAVIER AAND DIAS JM. 2007. Propagação vegetativa de árvores selecionadas de Eucalyptus cloeziana F. Muell por estaquia. Rev Árvore 31(3): 445-453.

BACCARIN FJB, BRONDANI GE, ALMEIDA LV, VIEIRA IG, OLIVEIRA LS AND ALMEIDA M. 2015. Vegetative rescue and cloning of Eucalyptus benthamii selected adult trees. New For 46(4): 465-483.

BEECKMAN T. 2010. Root development. Annual plant reviews, volume 37. Oxford, United Kingdom: J Wiley \& Sons Ltd, $365 \mathrm{p}$.

BITA CE AND GERATS T. 2013. Plant tolerance to high temperature in a changing environment: scientific fundamentals and production of heat stress-tolerant crops. Front Plant Sci 4(Article 273): 1-18.

BORGES SR, XAVIER A, OLIVEIRA LS, MELO LA AND ROSADO AM. 2011. Enraizamento de miniestacas de clones híbridos de Eucalyptus globulus. Rev Árvore 35(3): 425-434.

BRONDANI GE, BACCARIN FJB, BERGONCI T, GONÇALVES AN AND ALMEIDA M. 2014. Miniestaquia de Eucalyptus benthamii: efeito do genótipo, AIB, zinco, boro e coletas de brotações. Cerne 20(1): 147156.

BRONDANI GE, GROSSI F, WENDLING I, DUTRA LF AND ARAUJO MA. 2010a. Aplicação de IBA para o enraizamento de miniestacas de Eucalyptus benthamii Maiden \& Cambage $\times$ Eucalyptus dunnii Maiden. Acta Sci Agron 32(4): 667-674.

BRONDANI GE, WENDLING I, GROSSI F, DUTRA LF AND ARAUJO MA. 2010b. Miniestaquia de Eucalyptus benthamii $\times$ Eucalyptus dunnii: (II) sobrevivência e enraizamento de miniestacas em função das coletas e estações do ano. Ciênc Florest 20(3): 453-465.

BRONDANI GE, WIT ONDAS HW, BACCARIN FJB, GONÇALVES AN AND ALMEIDA M. 2012. Micropropagation of Eucalyptus benthamii to form a clonal micro-garden. In Vitro Cell Dev Biol Plant 48(5): 478-487.

COPPEN JJW. 2002. Eucalyptus: the genus Eucalyptus. London and New York: Taylor \& Francis, 464 p.

CORDEIRO GM, BRONDANI GE, OLIVEIRA LS AND ALMEIDA M. 2014. Meio de cultura, BAP e ANA na multiplicação in vitro de clones de Eucalyptus globulus 
Labill. Sci For 42(103): 337-344.

COSTA CT, ALMEIDA MR, RUEDELL CM, SCHWANBACH J, MARASCHIN FS AND FETTNETO AG. 2013. When stress and development go hand in hand: main hormonal control, of adventitious rooting in cuttings. Front Plant Sci 4(Article 133): 1-19.

DAYSTAR J, GONZALEZ R, REEB C, VENDITTI R, TREASURE T, ABT R AND KELLEY S. 2014. Economics, environmental impacts, and supply chain analysis of cellulosic biomass for biofuels in the Southern US: pine, Eucalyptus, unmanaged hardwoods, forest residues, switchgrass, and sweet sorghum. BioResources 9(1): 393-444.

DUTRA LF, WENDLING I AND BRONDANI GE. 2009. A micropropagação de eucalipto. Pesq Flor Bras 58: 49-59.

HARTMANN HT, KESTER DE, DAVIES JR FT AND GENEVE RL. 2011. Plant propagation: principles and practices. $8^{\text {th }}$ ed. São Paulo, SP, Brazil: Prentice-Hall, 915 p.

HUNG CD AND TRUEMAN SJ. 2011. Topophysic effects differ between node and organogenic cultures of the eucalypt Corymbia torelliana $\times$ C. citriodora. Plant Cell Tiss Organ Cult 104(1): 69-77.

JOVANOVIC T AND BOOTH TH. 2002. Improved species climatic profiles. Australia: Union Offset Printing, Joint Venture Agroforestry Program, Rural Industries Research and Development Corporation, $68 \mathrm{p}$.

KARNOVSKY MJ. 1965. A formaldehyde-glutaraldehyde fixative of high osmolality for use in eléctron microscopy. J Cell Biol 27(15): 137-138.

LI S-W, XUE L, XU S, FENG H AND AN L. 2009. Mediators, genes and signaling in adventitious rooting. Bot Review 75(2): 230-247.

LLOYD G AND MCCOWN B. 1980. Commercially-feasible micropropagation of mountain laurel, Kalmia latifolia, by use of shoot-tip culture. Comb Proc Int Plant Propag Soc 30: 421-427.

NOURISSIER S AND MONTEUUIS O. 2008. In vitro rooting of two Eucalyptus urophylla $\times$ Eucalyptus grandis mature clones. In Vitro Cell Dev Biol Plant 44(4): 263-272.

OBERSCHELP GPJ AND GONÇALVES AN. 2016. Assessing the effects of basal media on the in vitro propagation and nutritional status of Eucalyptus dunnii Maiden. In Vitro Cell Dev Biol Plant 52(1): 28-37.

OLIVEIRA LS, BRONDANI GE, BATAGIN-PIOTTO KD, CALSAVARA R, GONÇALVES AN AND ALMEIDA M. 2015. Micropropagation of Eucalyptus cloeziana mature trees. Aust For 78(4): 219-231.

OLIVEIRA LS, XAVIER A, DIAS PC, CORREIA ACG, BORGES SR, TAKAHASHI EK AND PAIVA HN. 2012. Enraizamento de miniestacas e microestacas de clones de Eucalyptus urophylla $\times$ E. globulus e de Eucalyptus grandis $\times$ E. globulus. Sci For 40(96): 507-516.

OLIVEIRA ML, XAVIER A, SANTOS AP AND ANDRADE HB. 2006. Efeito da estaquia, miniestaquia e micropropagação no desempenho silvicultural de clones híbridos de Eucalyptus spp. Rev Árvore 30(4): 503-512.

RUEDELL CM, ALMEIDA MR, SCHWAMBACH J, POSENATO CF AND FETT-NETO AG. 2013. Pre and post-severance effects of light quality on carbohydrate dynamics and microcutting adventitious rooting of two Eucalyptus species of contrasting recalcitrance. Plant Growth Regul 69(3): 235-245.

SAKAI WS. 1973. Simple method for differential staining of paraffin embedded plant material using toluidine blue $\mathrm{O}$. Stain Technol 48(5): 247-249.

SHANTHI K, BACHPAI VKW, ANISHA S, GANESAN M, ANITHAA RG, SUBASHINI V, CHAKRAVARTHI M, SIVAKUMAR V AND YASODHA R. 2015. Micropropagation of Eucalyptus camaldulensis for the production of rejuvenated stock plants for microcuttings propagation and genetic fidelity assessment. New For 46(3): 357-371.

SOARES NS, SILVA ML, REZENDE JLP AND GOMES MFM. 2010. Competitividade da cadeia produtiva da madeira de eucalipto no Brasil. Rev Árvore 34(5): $917-$ 928.

TITON M, XAVIER A, OTONI WC AND REIS GG. 2003. Efeito do AIB no enraizamento de miniestacas e microestacas de clones de Eucalyptus grandis W. Hill ex Maiden. Rev Árvore 27(1): 1-7.

TRIPATHY BC AND OELMÜLLER R. 2012. Reactive oxygen species generation and signaling in plants. Plant Signal Behav 7(12): 1621-1633.

TRUEMAN SJ, MCMAHON TV AND BRISTOW M. 2013. Production of cuttings in response to stock plant temperature in the subtropical eucalypts, Corymbia citriodora and Eucalyptus dunnii. New For 44(2): 265279.

WENDLING I, TRUEMAN SJ AND XAVIER A. 2014a. Maturation and related aspects in clonal forestry - part I: concepts, regulation and consequences of phase change. New For 45(4): 449-471.

WENDLING I, TRUEMAN SJ AND XAVIER A. $2014 \mathrm{~b}$. Maturation and related aspects in clonal forestry - part II: reinvigoration, rejuvenation and juvenility maintenance. New For 45(4): 473-486.

WENDLING I AND XAVIER A. 2001. Gradiente de maturação e rejuvenescimento aplicado em espécies florestais. Floresta Ambient 8(1): 187-194.

XAVIER A, WENDLING I AND SILVA RL. 2013. Silvicultura clonal: princípios e técnicas. Viçosa, MG, Brasil: Editora da UFV, 272 p. 